\title{
Zinc Sulfate in Narrow Range as an In Vitro Anti-HSV-1 Assay
}

\author{
Mona Fani ${ }^{1} \cdot$ Nastaran Khodadad ${ }^{1} \cdot$ Saeedeh Ebrahimi ${ }^{1} \cdot$ Rahil Nahidsamiei $^{1} \cdot$ Manoocher Makvandi $^{1}$. \\ Ali Teimoori ${ }^{1,2}$ (1) $\cdot$ Hadis Langari ${ }^{3}$
}

Received: 11 February 2019 / Accepted: 9 April 2019/Published online: 26 April 2019

(C) Springer Science+Business Media, LLC, part of Springer Nature 2019

\begin{abstract}
This report explains the employing of a combination test of traditional cell culture with a quantitative real-time PCR for assessment of the antiviral effect of zinc sulfate $\left(\mathrm{ZnSO}_{4}\right)$ on herpes simplex virus (HSV)-infected Vero cells. Our evidence showed that the treatment with $0.3 \mathrm{mM} \mathrm{ZnSO}_{4}$ strongly inhibited the replication of virus progeny (MOI 0.001) at least 68 -fold less. On the other hand, the IC50 demonstrated that the highest activity of $\mathrm{ZnSO}_{4}$ was at the $0.23 \mathrm{mM}$ concentration.
\end{abstract}

Keywords Herpes simplex virus $\cdot \mathrm{HSV} \cdot$ Zinc sulfate $\cdot$ Antiviral effect

\section{Introduction}

Viral infection is a primary and major cause of death among the human and animal infectious diseases in the world [1]. Herpes simplex virus type-1 (HSV-1) is one of the members of the Herpesviridae family, which frequently associated with several diseases including herpetic stomatitis, recurrent herpes labialis, erythema multiform, cranial neuropathies, and oral squamous carcinoma. HSV-1 is capable of causing lesions at or near the point of entry into the body and also can establish a latent infection in sensory ganglia. Subsequently, the latency often increases the HSV pathogenicity [2].

Antiviral medications including Acyclovir, Famciclovir, and Valacyclovir are effective drugs for people suffering from HSV infections. Although these drugs suppress the recurrence rate and viral shedding through the effects on viral DNA replication, their drawbacks include renal failure, anaphylaxis, and hepatitis [3]. Also, a considerable amount of literature has been published on HSV resistance to these antiviral drugs.

Mona Fani and Nastaran Khodadad contributed equally to this work.

Ali Teimoori

teimooriali1982@gmail.com

1 Infectious and Tropical Diseases Research Center, Health Research Institute, Ahvaz Jundishapur University of Medical Sciences, Ahvaz, Iran

2 Department of Virology, Faculty of Medicine, Hamadan University of Medical Sciences, Hamadan, Iran

3 Department of Modern Sciences and Technologies, School of Medicine, Mashhad University of Medical Sciences, Mashhad, Iran
Therefore, an effective and novel therapeutic strategy is required.

Recent evidence suggested that the use of natural substances such as lysine, vitamin C, zinc, vitamin E, and adenosine monophosphate may be beneficial for preventing the active infections or recurrences of herpes simplex [4]. It should be noted that several findings by researchers pointed the antiviral activity of zinc salts against a variety of viruses, including human immunodeficiency virus (HIV), human influenza A virus, equine arteritis virus (EAV), vaccinia virus, severe acute respiratory syndrome coronavirus (SARS $\mathrm{CoV})$, rhinovirus, and respiratory syncytial virus (RSV). Interestingly, zinc ions are used to treat these viral infections due to the hindrance of virus entry, a barrier of polyprotein processing or blocking the viral RNA-dependent RNA polymerase (RdRP) activity [5].

The antiviral effects of zinc ion on the HSV have been investigated by many researchers since 1967 [6]. Fridlender et al. in 1978 published a paper in which they described that the zinc ions reduced the activity of HSV DNA polymerase at a lower concentration than the cellular DNA polymerase. Furthermore, in vitro studies confirmed that $0.2 \mathrm{mM} \mathrm{ZnSO}_{4}$ significantly inhibited the HSV DNA replication by blocking the function of viral DNA polymerase and thus preventing the synthesis of viral proteins [7]. Also, other studies reported that zinc ions could interfere with the proper function of viral surface glycoproteins, resulting in blockage of virion penetration into the cells $[6,8]$.

To date, there is no study that focuses on the antiviral effect of $\mathrm{ZnSO}_{4}$ against HSV1-infected Vero cells based on the relative quantitative polymerase chain reaction (qRT-PCR) assay. QRT-PCR can provide a specific and sensitive method 
for determining the dynamics of virus proliferation and monitoring the treatment response.

\section{Material and Method}

\section{Virus Culture}

African green monkey kidney cells (Vero cells) (Razi Vaccine and Serum Research Institute, Karaj, Iran) were maintained in Dulbecco's modified Eagle's medium (DMEM) (Gibco, USA) supplemented with $10 \%$ fetal bovine serum (FBS) (Gibco, USA) and $100 \mathrm{IU} / \mathrm{ml}$ penicillin and $100 \mu \mathrm{g} / \mathrm{ml} \mathrm{strep-}$ tomycin (Sigma-Aldrich, USA) in $37^{\circ} \mathrm{C}$ in a humidified atmosphere containing $5 \% \mathrm{CO}_{2}$ for $48 \mathrm{~h}$.

Confluent monolayer cells in $75-\mathrm{cm}^{2}$ tissue culture flasks were infected by laboratory-adapted HSV-1 (KOS strain) at 0.01 and 0.001 multiplicity of infection (MOI). The flasks were incubated for $72 \mathrm{~h}$ at $37^{\circ} \mathrm{C}$ and HSV-1 infected cells were harvested through three freeze-thaw cycles and stored at $-70{ }^{\circ} \mathrm{C}$.

\section{Plaque Assay}

To calculate the MOI, Vero cells were cultured in a six-well plate (SPL, Korea) followed by incubation at $37{ }^{\circ} \mathrm{C}$ with $5 \%$ $\mathrm{CO}_{2}$ for $24 \mathrm{~h}$. Then, $0.5 \mathrm{ml}$ of different sixfold virus dilution $\left(10^{-2}\right.$ to $\left.10^{-6}\right)$ were inoculated to monolayer cells at $37^{\circ} \mathrm{C}$. After $1 \mathrm{~h}$ for virus adsorption, the inoculum was removed and cells were washed twice with phosphate-buffered saline (PBS) and covered with $3 \mathrm{ml}$ of overlay media containing the $2 \times$ DMEM (comprising of $4.5 \mathrm{~g} / \mathrm{L}$ D-glucose without L-glutamine) (Sigma-Aldrich, USA) with $1.5 \%$ agarose gel at 1:1 (2× DMEM:agarose gel) ratio. The plate was incubated at $37{ }^{\circ} \mathrm{C}$ in $5 \% \mathrm{CO}_{2}$ for $72 \mathrm{~h}$. After plaque formation, second agar overlay containing neutral red was added to visualize the plaques with the naked eye and the plate was incubated at $37{ }^{\circ} \mathrm{C}$ in $5 \% \mathrm{CO}_{2}$.

\section{Cytotoxicity Test by MTT Assay}

To evaluate the $\mathrm{ZnSO}_{4}$ cytotoxicity, the MTT assay (3-(4,5dimethylthiazol-2-yl)-3,5-diphenyl tetrazolium bromide) (Sigma) was performed.

Vero cells were passaged $\left(5 \times 10^{3}\right.$ cells/well $)$ in a 96 -well plate (SPL, Korea) and the plate was incubated at $37^{\circ} \mathrm{C}$ with $5 \% \mathrm{CO}_{2}$ for $24 \mathrm{~h}$. The medium was replaced with DMEM medium containing various concentrations of $\mathrm{ZnSO}_{4}$ and the plate was incubated for $72 \mathrm{~h}$. The culture medium was removed and $5 \mathrm{mg} / \mathrm{mL}$ MTT in PBS was added to each well, and the plate was incubated for $4 \mathrm{~h}$ at $37^{\circ} \mathrm{C}$. After removal of supernatant, $50 \mu \mathrm{L}$ of dimethyl sulfoxide (DMSO) was added to each well and the plate incubated for $20 \mathrm{~min}$ at $37^{\circ} \mathrm{C}$ with
$5 \% \mathrm{CO}_{2}$. Then, the optical density (OD) was measured at $570 \mathrm{~nm}$ using the ELISA plate reader.

Finally, the viability of cells was calculated using the following equation:

$$
\begin{aligned}
& \text { Percentage of cell viability } \\
& \quad=(\text { Test } 570 \mathrm{~nm}-620 \mathrm{~nm} / \text { Control } 570 \mathrm{~nm}-620 \mathrm{~nm}) \times 10
\end{aligned}
$$

\section{Relative Quantitative PCR}

Vero cells were grown to about $70 \%$ confluence in a 96-well plate and infected with HSV-1 (MOI: 0.01 and 0.01) and treated with $\mathrm{ZnSO}_{4}$ at various concentrations (100-300 $\left.\mu \mathrm{M}\right)$. After $72 \mathrm{~h}$ incubation, the culture medium was collected, and total DNA extracted from medium using the high pure viral nucleic acid kit (Roche, Germany). Then, qRT-PCR was performed using QuantiTect Probe PCR Kits (Qiagen, Germany). Samples were examined in a $20-\mu \mathrm{L}$ reaction containing $10 \mu \mathrm{L}$ of the $2 \times$ Master mix, $0.2 \mu \mathrm{L}$ probe, $0.4 \mu \mathrm{L}(5 \mathrm{pmol})$ each of forward and reverse primers, $8 \mu \mathrm{L}$ of nuclease-free water, and $1 \mu \mathrm{L}$ of DNA. The PCR thermal profile consisted of $95^{\circ} \mathrm{C}$ for $2 \mathrm{~min}$ ( 1 cycle), $95^{\circ} \mathrm{C}$ for $30 \mathrm{~s}$, and $60{ }^{\circ} \mathrm{C}$ for $15 \mathrm{~s}$ (35 cycles, respectively). Positive and negative controls were also included in all experiments, and each sample was analyzed in triplicate.

A 96-bp segment of gB gene was amplified using primers and probe which are listed in Table 1. The TaqMan probe was designed for HSV-1 specifically and confirmed by Primer Blast algorithms.

\section{Results}

\section{Herpes Simplex Type 1 Toxicity Assay}

Unlike to normal cell group, HSV1-infected Vero cells became rounded and also, some of them detached from the bottom of the plates. In this study, over $50 \%$ of the cells exhibited cytopathic effect (CPE) after $72 \mathrm{~h}$. The HSV-1-induced CPE in Vero cells is presented in Fig. 1.

\section{Cytotoxicity of $\mathrm{ZnSO}_{4}$ to Cultured Cells}

Before the determination of inhibitory concentration of $\mathrm{ZnSO}_{4}$ on HSV-1 replication, cells were exposed to the increased concentrations of $\mathrm{ZnSO}_{4}$ and the viability monitored by MTT technique as a colorimetric assay. Figure 3 implicates the cytotoxicity effect of $\mathrm{ZnSO}_{4}$ in Vero cells. According to the results, the IC50 showed the strong influence of $\mathrm{ZnSO}_{4}$ at the $0.23 \mathrm{mM}$ concentration. 
Table 1 The all oligonucleotides sequences were used in this study

\begin{tabular}{lll}
\hline Gene & Primer $\left(5^{\prime}-3^{\prime}\right)$ & Probe $\left(5^{\prime}-3^{\prime}\right)$ \\
\hline $\mathrm{gB}$ & Forward: TCCAGCATGGTGATGTTGAG & FAM-ATCACCACCGTCAGCACCTTCATCG- BHQ1 \\
& Reverse: CGTGTACTTCGAGGAGTACG & \\
\hline
\end{tabular}

\section{Evaluation of the Real-time PCR Assay}

We compared the effect of $\mathrm{ZnSO}_{4}$ on relative change of HSV1 DNA replication in treated infected cells (as a test group) and infected cells (as a control group) using qRT-PCR. To determine the level of expression, the differences of threshold cycles $(\Delta \mathrm{Ct})$ between the test and the control group were measured. To achieve optimal relative expression results, appropriate normalization strategies were applied to reduce experimental error, and also HSV-1 (MOI: 0.001 and 0.01) was added to both test and control groups (Fig. 2a, b).

\section{Discussion}

Our interest in the zinc effect on HSV replication was due to the several previous studies on the potential activity of zinc ions against laboratory-adapted strains of HSV.

As mentioned, an early in vitro study in 1978 by Fridlender et al. showed the inhibitory effect of zinc salt on HSV-1 DNA polymerase [7]. Also, this result was gained by Gordon et al. and Shlomai et al. to describe blocking of HSV1 DNA in vivo [9, 10]. Generally, the previous studies claimed that the zinc concentrations of $0.1 \mathrm{mM}$ and $0.2 \mathrm{mM}$



Fig. 1 Microscopic morphology of HSV-1 propagation in Vero cells inhibited the production of virion progeny in HSV-infected cells. Also, zinc ions at the concentration of $0.3 \mathrm{mM}$ were cytotoxic and induced the cell death. According to an investigation by Arens et al., the degree of inhibition seemed to depend on the type and strain of HSV and also the zinc salt form [8]. In another study by Kumel et al. using Electron microscopy, they showed that there was a correlation between the depositions of zinc onto the viral surface glycoproteins and inhibition of virion penetration into African green monkey kidney (AGMK) cells [6].

As shown in Fig. 2a, we found that there was a significant decline in the amount of replication of virion progeny (MOI 0.001 ) isolated from HSV-infected Vero cells in the presence of $0.3 \mathrm{mM} \mathrm{ZnSO}_{4}$. Based on the data in Fig. 3, it is apparent that $\mathrm{ZnSO}_{4}$ concentration of $0.23 \mathrm{mM}$ is toxic to Vero cells. But there is no meaningful difference between 0.23 and $0.2 \mathrm{mM}$. So, we concluded that the virus inactivation was probably due to the cytotoxicity of $\mathrm{ZnSO}_{4}$ instead of

a Effect of ZnSo4 with MOI: 0.001

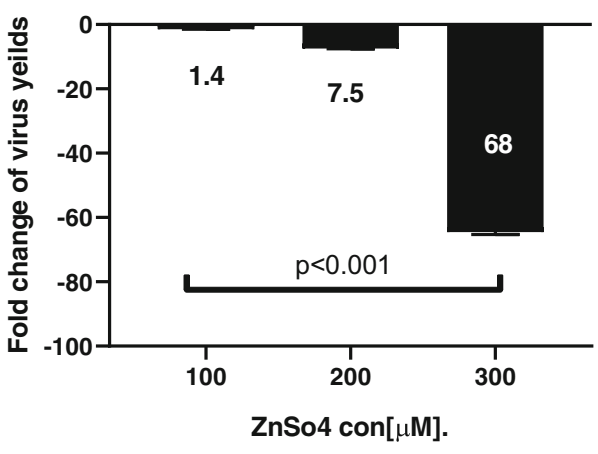

MOI .001

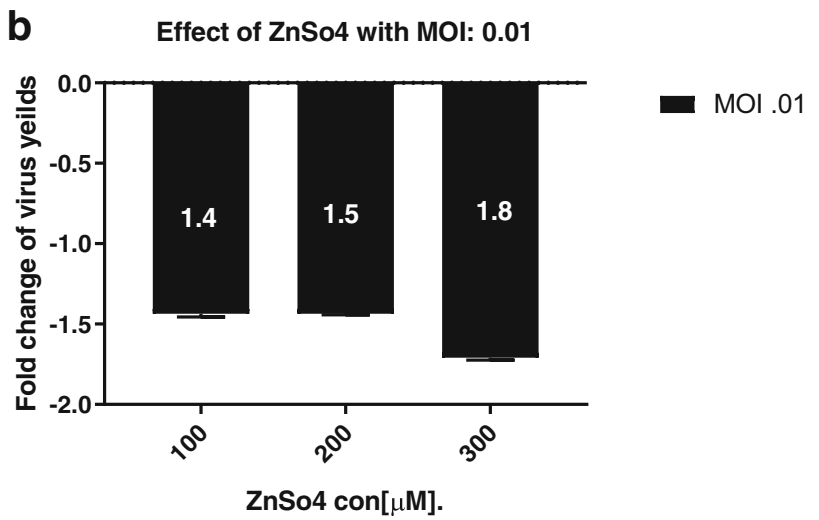

Fig. 2 Inhibitory effects of various concentrations of $\mathrm{ZnSO}_{4}$ on $\mathrm{HSV}-1$ (strain KOS)-infected Vero cells at 0.001 (a) and $0.01 \mathrm{MOI}$ (b) 


$$
\begin{gathered}
\mathrm{IC}_{50 \%}=233.1 \\
\mathrm{R}^{2}=0.83
\end{gathered}
$$

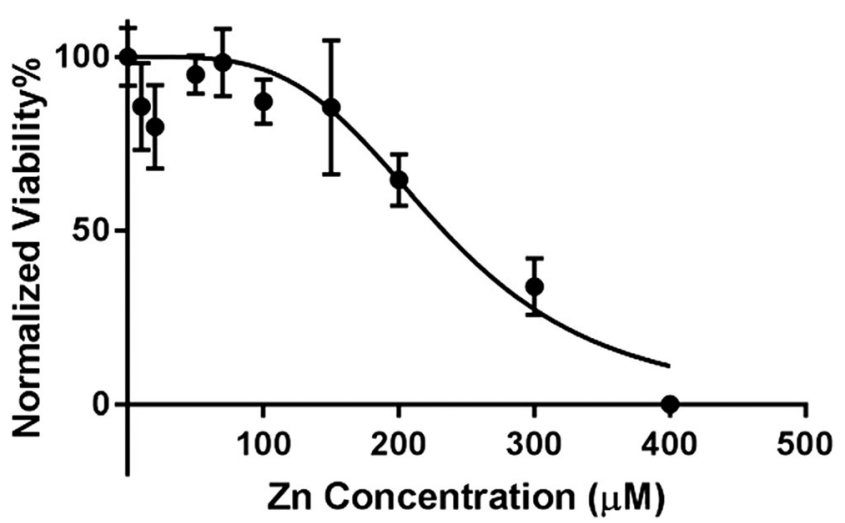

Fig. 3 Viability percentage of Vero cells in exposure to increasing concentrations of $\mathrm{ZnSO}_{4}$

interfering with adsorption and penetration processes, in contrast to the results by Kumel [6]. Also, we highlight the proposed hypothesis by Arens who concluded that several factors should be considered for inhibition of zinc-treated infected cells, such as the type of virus and cell, HSV strain, and salt form [8]. Furthermore, we showed that the MOI ratio was another important factor for the effect of zinc ions on this process.

It should be noted that we also mixed the virus and $\mathrm{ZnSO}_{4}$ and added them to Vero cells that showed similar results.

This research has thrown up many questions in need of further investigation. In addition, more studies are required on monitoring the treated infected cell by qRT-PCR technique. Also, to assess the $\mathrm{ZnSO}_{4}$ uptake, the intracellular zinc content in Vero cells should also be measured after the exposure of cells to the $\mathrm{ZnSO}_{4}$.
Acknowledgments This work was supported by Infectious and Tropical Diseases Research Center, Health Research Institute and Department of Virology, Faculty of Medicine, Ahvaz Jundishapur University of Medical Sciences, Ahvaz, Iran.

\section{References}

1. Wolfe ND, Dunavan CP, Diamond J (2007) Origins of major human infectious diseases. Nature. 447(7142):279-283

2. Whitley RJ, Nahmias AJ, Visintine AM, Fleming CL, Alford CA, Yeager A et al (1980) The natural history of herpes simplex virus infection of mother and newborn. Pediatrics. 66(4):489-494

3. Pasternak B, Hviid A (2010) Use of acyclovir, valacyclovir, and famciclovir in the first trimester of pregnancy and the risk of birth defects. JAMA 304(8):859-866

4. Gaby AR (2006) Natural remedies for herpes simplex. Altern Med Rev 11(2):93

5. Jiang Y-C, Feng H, Lin Y-C, Guo X-R (2016) New strategies against drug resistance to herpes simplex virus. Int J Oral Sci $8(1): 1-6$

6. Kümel G, Schrader S, Zentgraf H, Daus H, Brendel M (1990) The mechanism of the antiherpetic activity of zinc sulphate. J Gen Virol 71(12):2989-2997

7. Fridlender B, Chejanovsky N, Becker Y (1978) Selective inhibition of herpes simplex virus type 1 DNA polymerase by zinc ions. Virology 84(2):551-554

8. Arens M, Travis S (2000) Zinc salts inactivate clinical isolates of herpes simplex virus in vitro. J Clin Microbiol 38(5):1758-1762

9. Gordon YJ, Asher Y, Becker Y (1975) Irreversible inhibition of herpes simplex virus replication in BSC-1 cells by zinc ions. Antimicrob Agents Chemother 8(3):377-380

10. Shlomai J, Asher Y, Gordon YJ, Olshevsky U, Becker Y (1975) Effect of zinc ions on the synthesis of herpes simplex virus DNA in infected BSC-1 cells. Virology. 66(1):330-335

Publisher's Note Springer Nature remains neutral with regard to jurisdictional claims in published maps and institutional affiliations. 